\title{
Customer Satisfaction on Service Quality of Bus Transport: A Survey of Passengers from Phnom Penh to Poipet in Cambodia
}

\author{
Sokchan Ok \\ Faculty of Science, School of Logistics and Supply Chain, Naresuan University, \\ 99 Moo 9 Tambon Tha Pho, Muang Phitsanulok 65000, Thailand \\ E-mail: oksokchan@yahoo.com \\ Prof. Thammanoon Hengsadeekul (Advisor) \\ Faculty of Science, School of Logistics and Supply Chain, Naresuan University, \\ 99 Moo 9 Tambon Tha Pho, Muang Phitsanulok 65000, Thailand \\ E-mail: thammanoonh@gmail.com
}

Received: April 15, 2018 Accepted: May 10, 2018 Published: May 12, 2018

doi: 10.5296/jsss.v5i2.13020ＵRL: http://doi.org/10.5296/jsss.v5i2.13020

\begin{abstract}
This study is designed to evaluate the main factors affecting the bus service quality and customer satisfaction in bus services to travel from Phnom Penh to Poipet which are providing by private companies. It examines and explores the consumer expectation on service quality of bus transport through the SERVQUAL's 5 dimensions such as tangible, reliability, assurance, empathy, and responsiveness. This research study is intended to collect data from participants to investigate the relationship among five components of service quality and customer satisfaction. The independent variable used throughout this study is overall satisfaction with bus transport service. Independent variables are specific service quality attributes which consist of service given, access, availability, time and environment. From the finding, on interesting finding was that in the question of customer's reason to use the BTS of private companies in Cambodia, in which "suitable traveling" ranked last among other factor (location convenience, appreciate price, no choice, good service). Also, more than half of the respondents stated they maybe use the BTS again in the future, because there
\end{abstract}


is no choice for them. Therefore, it can be clearly seen that this research was focusing at right point. Despite the fact that half of the respondents rated their satisfaction level of the "poor" level, and nearly half of the respondents rated their satisfaction level in "average" level. Nevertheless, not so many customers preferred to use the BTS because of its service convenience. Service quality is an important consideration in a successful service business. By the time, this research was conducted, the highly competitive market conditions in Cambodia's bus transport service industry had forced service operators to deliver high-quality service to customers. In order to provide that, the service operators should first focus on understanding customers' needs and their expectations before implementing the suitable service strategy to meet the customers' needs.

Keywords: Bus Transport, Customer's satisfaction, Customer's expectation, Service quality, SERVQUAL

\section{Introduction}

Bus transportation is a key travelling way for global travelers. It offers linkage between destinations and transports customers for goods and service (Eden, 2005). Nowadays, every kind of people utilize transportation sector to travel anywhere. Bus transportation is a part of the transport sector services available in Cambodia. Bus transportation plays a vital role as the main transportation for all people, especially for poor and fair income families.

This study is intended to learn and how to improve the customer's satisfaction in private bus companies. The satisfaction can be characterized as an experience of fulfillment of an expected outcome (Rabiul, Mohammed S., Mohammad, \& Salauddin, 2014). The quality is increasingly becoming a strategic issue in the Western world (David \& Prof. Henry M., 2014), and also in Cambodian situation. Customer satisfaction is considered to be the most important factor whether it is meant for a product or a service. In case of failure to satisfy customers, company will be replaced by others and when industries offering various services, have to be more vigilant because there is a special attitude that plays an important role in attracting and retaining the customers (Rida, Hummayoun, Sana, Faiza, \& Taha, 2012). Customer expectations are beliefs about service delivery that serves as standards or reference points against which performance is judged (Veronica, Jacqueline, \& Melissa-Ray, 2015).

This study aims to evaluate the main factors affecting the bus service quality and customer satisfaction in bus services to travelling from Phnom Penh to Poipet which are providing by private companies. It examines and explores the customer expectation on service quality of bus transport through the SERVQUAL's 5 dimensions such as tangible, reliability, assurance, empathy, and responsiveness.

\section{Literature Review}

Service quality appraisals are created on judgments of result quality, interaction quality and physical environmental quality. Service quality constitutes one of the key measurements, which are figured into the customer's satisfaction judgments (Zeithami Valarie A., Parasuraman, \& Leonard L., 1990). Services are created and expanded in the meantime, which makes it hard to gauge; test and thusly particular uniform quality can seldom be set. 
Subsequently, it is notoriously difficult to decide how customers assess the service quality (Parasuraman, Valarie A., \& Leonard L., 1985). On the other hand, the heterogeneity of service suggests its delivery differs from producer to producer, consumer to consumer and day-to-day (Parasuraman et al., 1985).

Accordingly, if a service over and again neglects to experience the customer's expectations it will be seen as poor service. Furthermore, in services to customers assess the service procedure and additionally the ultimate result (Hoffman \& Bateson, 2006). On account of transport travel, that will be whether the transport leaves on an opportune way, how smooth the excursion was, the manner by which lovely the experience with the transport conductor was and on the off chance that they landed at their last goal on time.

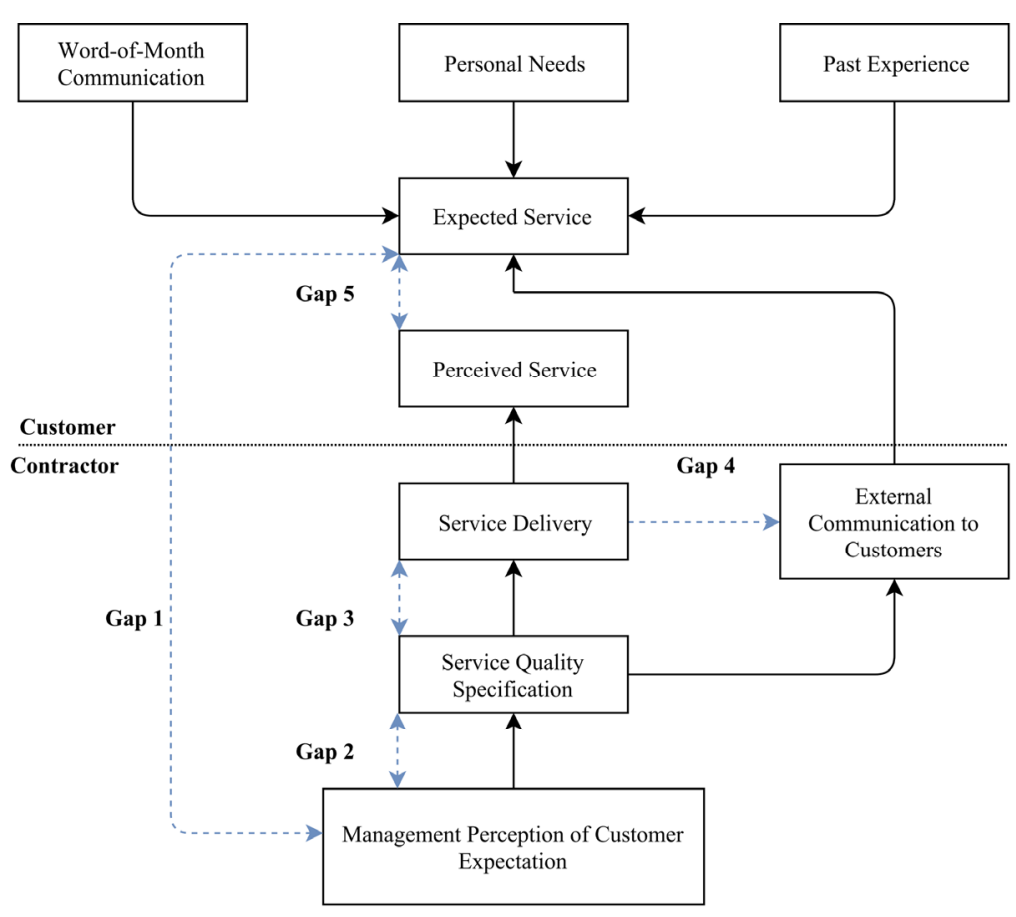

Figure 1. The model of gaps

Source: Parasuraman, Zeithaml and Berry (1988)

The figure was indicated that proposed five gaps crevices as take after: Gap 1 is the hole between customer perception and management's perception of service; Gap 2 is the hole between Customer-driven service plans and gauges, and management perceptions of customer expectation; Gap 3 is the hole between customer - driven outlines and norms and service delivery; Gap 4 is the hole between service delivery and outer correspondences to customers; and Gap 5 is the structure of the other four gaps' disagreement that suggested the between service quality's expectation and perception (Candido \& Morris, 2000).

There are many reviews on "customer expectation" to figure out what customers truly require, 
so that business operations can quickly offer the products and service that can take care of customers' needs and demand. Pervious research said expectation as "desires or needs of customers which are what they feel a service provider ought to offer instead of would offer" (Parasuraman, Valarie A., \& Leonard L., 1988); as the customers' past experience will probably influence their future expectation (Zeithaml Valarie A., Leonard L., \& Parasuraman, 1993). At the end of the day, customers' expectations influence the arrangement of their satisfaction inside discriminative circumstances and furthermore the expectation is some of the time more significant just when they are unambiguous (Nyer, 1996). After customer experienced great service, they would inform other regarding the service quality of the supplier. Thus, if service providers comprehend their customer's preference along service quality estimations and staying to give some quality of service which will precisely diminish the gaps in service quality between customers and satisfied by the service providers those great words from the customer's preference on service quality will acquire unwaveringness from the other service users (Manjunatha \& Shivalingaiah, 2004).

Customer satisfaction was given a few definitions which can be in various circumstances and they are constantly identified with both products and services. Customer satisfaction was characterized as the customer's evaluation a product or service as far as whether that product or service has the customer's needs and expectations (Alan, Valarie A., Mary Jo, \& Dwayne D., 2012). The definition and specified that customer satisfaction is an effective term and they distinguish five unique sorts of satisfaction, which is pleasure, relief, novelty and surprise (Oliver \& Swan, 1989). Customer satisfaction has likewise turned into a noteworthy benefactor for improving a service company, for example, long-term gratefulness, customer dependability customer maintenance. Numerous analysts additionally contend that customer satisfaction has a big effects customer expectation for repurchase (Cronin Jr, Brady, \& Hult, 2000). The measuring customer satisfaction gives a sign on how an organization is performing or giving products or services; hence, customer satisfaction will be the degree of accomplishment to every one of the organizations including the public sectors too (Tirimba O., Richard B., Robert M., Thomas O., \& Tom O., 2013).
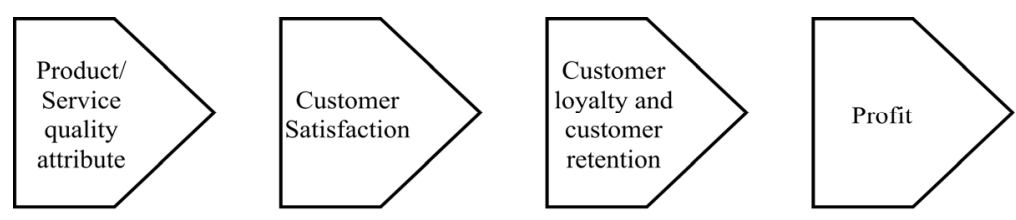

Figure 2. The Chain Reaction Model of customer

Source: Eugene \& Vikas (2000)

This figure shows about the model of chain that was indicated by Eugene \& Vikas (2000). The item and service quality traits when were enhanced, the customers' satisfaction would extend as the expanding number of customer satisfaction dependably prompt more noteworthy greater customer retention and loyalty (Eugene \& Vikas, 2000). These would lead 
the association to increment more prominent gainfulness.

The SERVQUAL scale which is otherwise called the crevice to demonstrate by Parasuraman, et al. (1988) has appeared to be one of the most ideal approaches to gauge the quality of services gave to customers. This service assessment technique has been demonstrated steady and dependable by some authors (Brown, Churchill, \& Peter, 1993). They held that, when seen or experienced service is not as much as the expected service; it infers not as much as palatable service quality; and when seen service is more than anticipated service, the undeniable surmising is that service quality is more than acceptable (Jain \& Gupta, 2004).

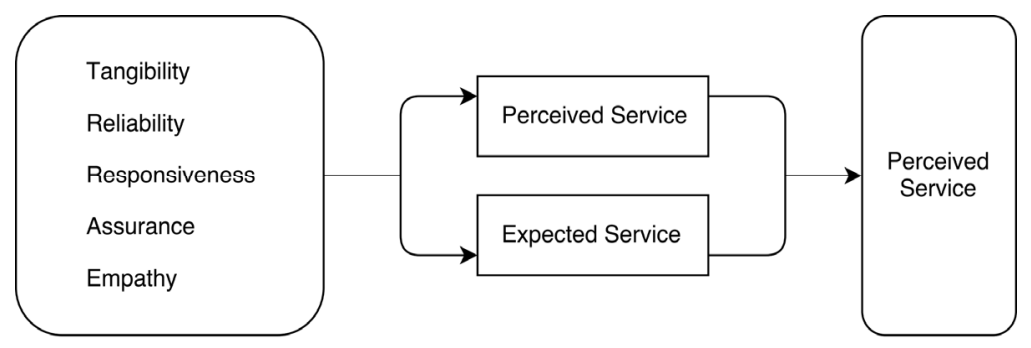

Figure 3. The Model of SERVQUAL

Source: Parasuraman, Zeithaml and Berry (1988)

This figure is to show on account of when it is expressed "perceived" and "expected" service; it is certain this goes to the individual, who is going to or is devouring the service; who unquestionably is the consumer/customer (Jenet Manyi, 2011). In first SERVQUAL show that came had 22 sets of Likert-sort things, where one section measured saw level of service gave for a specific association and the other part measured expected level of service quality by respondent (Kuo, 2003). Assistant examination prompted the finding that the five of ten measurements were corresponded as demonstrated as follows: (1) Tangibility: physical offices, hardware, and appearance of faculty; (2) Reliability: capacity to play out the guaranteed service constantly and precisely; (3) Responsiveness: readiness to help customers and give incite service; (4) Assurance: learning and obligingness of employees and their capacity to move trust and confidence; and (5) Empathy: minding individualized consideration the firm gives to its customers.

In relating customer satisfaction and service quality, scientists have been more exact about the significance and estimations of satisfaction and service quality. Satisfaction and service quality have certain things in like manner; however satisfaction by and large is a more extensive idea, though service quality concentrates particularly on measurements of service (Alan et al., 2012). In spite of the fact that it is expressed that different elements, for example, cost and item quality can influence customer satisfaction, saw service quality is a part of customer satisfaction (Zeithaml Valarie A., Mary Jo, \& Dwayne, 2006). 


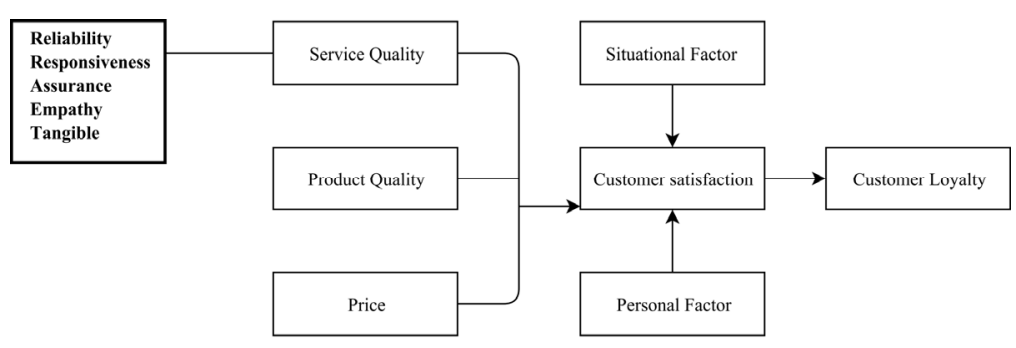

Figure 4. Customer perceptions of quality and customer satisfaction

Source: Alan Wilson et al., (2012)

The above figure demonstrates the relationship between customer satisfaction and service quality. The creator exhibited a circumstance that service quality is an engaged assessment that mirrors the customer's perception of reliability, assurance, responsiveness, empathy and tangibility and substantial quality while satisfaction is more comprehensive and it is affected by view of service quality, item quality and cost, likewise situational components and individual variables (Alan et al., 2012).

\section{Research Design}

This research study is designed to collect data from participants to investigate relationship among five components of service quality and customer satisfaction. The research used both qualitative and quantitative. The independent variable used throughout this study is overall satisfaction with bus transport service. Independent variables are specific service quality attributes which consist of service given, access, availability, time and environment.

These are the five dimensions of service quality deduced from service quality literatures.

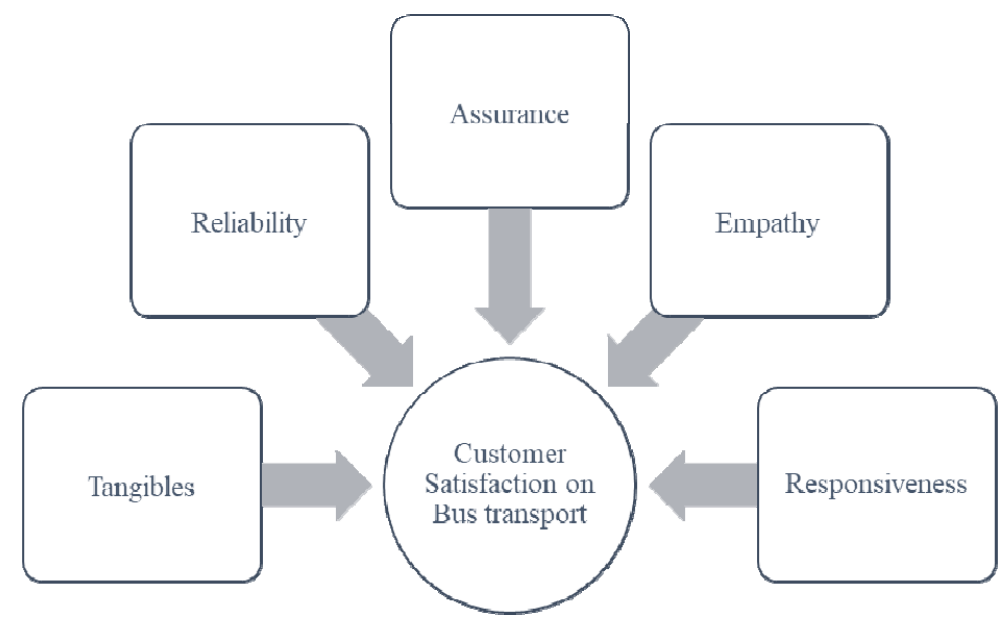

Figure 5. Theoretical framework

This research conducted through the questionnaire with 400 respondents to find out of both Cambodian and foreigners who has experience in using bus services to travelling from 
Phnom Penh to Poipet. The questionnaire consisted of 3 sections as follow:

1) Demographic information: (gender, age, nationality, education, occupation, times of travel, reason to choose bus transport services, will use the services again, overall satisfaction level).

2) This section is measures the customer's expectation that relate to 5 dimension of SERVQUAL (Tangibles, Reliability, Assurance, Empathy, and Responsiveness). The rating as below:

Strongly poor

1 point

Poor

2 point

Average

3 point

Good

4 point

Excellence

5 point

3) This sector is a freely recommend how bus transport sector should improve their services through customers' recommendations and suggestions.

\section{Results}

\subsection{Demographical and General Results}

This section presents the frequency and percentage in general information of the respondents.

Table 1. Summarize of demographical and general result

\begin{tabular}{lll}
\hline Category & Frequency $(400)$ & Percentage $(100 \%)$ \\
\hline Gender & 217 & 54.3 \\
Male & 183 & 45.8 \\
Female & & \\
Age (Year) & 93 & 23.3 \\
Less than, or 24 & 163 & 40.8 \\
$25-35$ & 76 & 19.0 \\
$36-45$ & 57 & 14.3 \\
$46-60$ & & \\
\hline
\end{tabular}


Above 60

11

2.8

Nationalities

Cambodian

American

Russian

Vietnamese

German

Japanese

Thai

French

Korean

Chinese

4

English

Indonesian

Education

Less than high school

High school

Bachelor degree

Master degree

Above Master degree

Occupation

Student

Farmer

Government Officer

Private Staff

Business Owner

Other

0.8 
Average Income

Less than 120 USD

10.8

121-250 USD

149

37.3

251-500 USD

63

15.8

501-1000 USD

97

24.3

Above 1000 USD

48

12.0

Frequency of time

Morning

Afternoon

11.8

Evening

Night

Frequency of day

Working day

Weekend

Short Holiday

Long Holiday (Festival)

Purpose of traveling

Business

Visiting friends or family

Leisure

Transport

Reason to use BTS

Appreciate Price

Suitable Travelling

Location Convenience

Good Service 
Will to used BTS next time

Exactly

Maybe

No with what choice?

Overall Satisfaction

Extremely poor

Poor

Average

Good

According to the result, table 2 shows that the total number of the respondent was 400; of this 217 (or $54.3 \%$ ) were male, and 183 (or $45.8 \%$ ) were female. In terms of age, the majority of the respondents ( 163 or $40.8 \%$ ) were in the group with the ages of $25-35$, followed by those with the age of less than or 24 (93 or 23.3\%), those with the ages of 36-45 (76 or 19.0\%), those with the ages of 46-60 (57 or 14.3\%), and those with the ages above 60 (11 or $2.8 \%$ ), respectively. Regarding to the respondents' nationality, the majority (351 or $87.8 \%$ ) were Cambodian, followed by American and French (7 or 1.8\%), English (6 or 1.5\%), Thai and Korean (5 or 1.0\%), Russian and Chinese (4 or 1.0\%), German, Japanese and Indonesian (3 or $0.8 \%$ ), and Vietnamese ( 2 or $0.5 \%$ ), respectively. As to the respondents' educational level, the majority were Bachelor's degree holders (151 or 37.8\%), followed by holders of Master's degree (117 or $29.3 \%$ ), High school (60 or $15.0 \%$ ), holders of degrees higher than Master degree (40 or $10.0 \%$ ), and less than high school (30 or $8.0 \%$ ), respectively. As regards their occupation the majority were Private staff (115 or 28.8\%), followed by student (102 or $25.5 \%$ ), Government officer ( 80 or $23.3 \%$ ), Farmer (41 or $10.3 \%$ ), and other occupation ( 3 or $0.8 \%$ ). Concerning their purpose of traveling, visiting friends or family was the main purpose of their traveling (197 or $49.3 \%$ ), followed by leisure (142 or $35.5 \%$ ), business ( 50 or $12.5 \%$ ), and transport (11 or $2.8 \%$ ), respectively. Regarding the reason that the respondents chose to use the BTS, the suitable traveling was the main reason (158 or $95.5 \%$ ), followed by location convenience (148 or $37.0 \%$ ), appreciate prince ( 73 or $18.3 \%$ ), no choice (12 or $3.0 \%$ ), and good service ( 9 or $2.3 \%$ ), respectively. When asked if they would travel by the BTS again, the majority of the respondents (253 or $36.3 \%$ ) said that they might, 144 or $36.0 \%$ they would exactly use the BTS again in the future, and only 3 or $0.3 \%$ said they would not use the BTS again. Regarding their satisfaction level of the BTS, the majority of the respondents (154 or $38.5 \%$ ) rated the BTS at poor; 131 or $22.8 \%$, at an average level; 79 or $19.8 \%$ at an extremely poor level; and 36 or $9.0 \%$ at good level, respectively. 


\subsection{SERVQUAL's 5 Dimensions Results}

This section indicates the frequency and percentage data of expectation of the respondents depended on SERVQUAL's 5 dimensions. The questionnaires' results are sorted by dimension. The number 1-5 in the table represents the satisfaction rating, which shows as follows; 1) Strongly poor; 2) Poor; 3) Average; 4) Good; and 5) Excellence

4.2.1 Tangibles

Table 2. Customer's distribution of Tangible dimension based on expectation

\begin{tabular}{|c|c|c|c|c|c|c|c|c|}
\hline & & 1 & 2 & 3 & 4 & 5 & Mean & S.D \\
\hline \multirow{2}{*}{$\begin{array}{l}\text { 1.Bus station } \\
\text { facilities } \\
\text { comfortable }\end{array}$} & Frequency & 84 & 188 & 94 & 24 & 10 & \multirow[t]{2}{*}{2.22} & \multirow[t]{2}{*}{0.929} \\
\hline & Percentage & 21.0 & 47.0 & 23.5 & 6.0 & 2.5 & & \\
\hline \multirow{2}{*}{$\begin{array}{l}\text { 2.Inside environment } \\
\text { of bus is clean and } \\
\text { hygienic }\end{array}$} & Frequency & 80 & 232 & 54 & 20 & 14 & \multirow{2}{*}{2.14} & \multirow{2}{*}{0.912} \\
\hline & Percentage & 20.0 & 58.0 & 13.5 & 5.0 & 3.5 & & \\
\hline \multirow{2}{*}{$\begin{array}{l}\text { 3.Cleanliness of } \\
\text { facilities and } \\
\text { equipment }\end{array}$} & Frequency & 75 & 226 & 61 & 21 & 14 & \multirow{2}{*}{2.17} & \multirow[b]{2}{*}{0.920} \\
\hline & Percentage & 19.5 & 56.5 & 15.3 & 5.3 & 3.5 & & \\
\hline \multirow{2}{*}{$\begin{array}{l}\text { 4. Buses have } \\
\text { spacious and comfort } \\
\text { seats for the } \\
\text { passenger }\end{array}$} & Frequency & 77 & 200 & 83 & 24 & 16 & \multirow[b]{2}{*}{2.26} & \multirow[b]{2}{*}{0.968} \\
\hline & Percentage & 19.3 & 50.0 & 20.8 & 6.0 & 4.0 & & \\
\hline \multirow{2}{*}{$\begin{array}{l}\text { 5. Buses have ample } \\
\text { legroom and foot } \\
\text { space }\end{array}$} & Frequency & 76 & 226 & 61 & 23 & 14 & \multirow{2}{*}{2.18} & \multirow{2}{*}{0.925} \\
\hline & Percentage & 19.0 & 56.5 & 15.3 & 5.8 & 3.5 & & \\
\hline
\end{tabular}

In Table 2 presents to the satisfaction rating on tangible dimension which shows as follows: 1) Bus station and facilities are comfortable (Poor 47.0\%; Average 23.5\%; Strongly Poor 21.0\%; Good 6.0\%; and Excellence 2.5\%); 2) Inside environment of bus is clean and hygienic (Poor 58.0\%; Strongly Poor 20.0\%; Average 13.5\%; Good 5.0\%; and Excellence 3.5\%); 3) Cleanliness of facilities and equipment (Poor 56.5\%; Strongly Poor 19.5\%; Average 15.5\%; Good 5.0\%; and Excellence 3.5\%); 4) Buses have spacious and comfort seats for the passenger (Poor 50.0\%; Average 20.8\%; Strongly Poor 19.2\%; Good 6.0\%; and Excellence $4.0 \%$ ); and 5) Buses have ample legroom and foot space equipment (Poor 56.5\%; Strongly 
Poor 19.0\%; Average 15.3\%; Good 5.8\%; and Excellence 3.5\%). Therefore, with the results in table 3 indicates that almost customers rated on the satisfaction and expectoration of tangible dimension at "Poor".

\subsubsection{Reliability}

Table 3. Customer's distribution of Reliability dimension based on expectation

\begin{tabular}{|c|c|c|c|c|c|c|c|c|}
\hline & & 1 & 2 & 3 & 4 & 5 & Mean & S.D \\
\hline \multirow{2}{*}{$\begin{array}{l}\text { 1. Accuracy of } \\
\text { ticketing and billing } \\
\text { services }\end{array}$} & Frequency & 77 & 174 & 105 & 29 & 15 & \multirow{2}{*}{2.23} & \multirow{2}{*}{0.989} \\
\hline & Percentage & 19.3 & 43.5 & 26.3 & 7.3 & 3.8 & & \\
\hline \multirow{2}{*}{$\begin{array}{l}\text { 2. Buses departure } \\
\text { and arrives at the } \\
\text { punctual time }\end{array}$} & Frequency & 106 & 221 & 36 & 22 & 15 & \multirow{2}{*}{2.05} & \multirow{2}{*}{0.955} \\
\hline & Percentage & 26.5 & 55.3 & 9.0 & 5.5 & 3.8 & & \\
\hline \multirow{2}{*}{$\begin{array}{l}\text { 3. Safe and security } \\
\text { service }\end{array}$} & Frequency & 108 & 176 & 61 & 21 & 14 & \multirow{2}{*}{2.14} & \multirow{2}{*}{0.990} \\
\hline & Percentage & 27.0 & 44.0 & 20.3 & 5.3 & 3.5 & & \\
\hline \multirow{2}{*}{$\begin{array}{l}\text { 4. Buses are never } \\
\text { break down on the } \\
\text { road }\end{array}$} & Frequency & 106 & 170 & 86 & 23 & 15 & \multirow{2}{*}{2.18} & \multirow{2}{*}{1.009} \\
\hline & Percentage & 26.5 & 42.5 & 21.5 & 5.8 & 3.8 & & \\
\hline \multirow{2}{*}{$\begin{array}{l}\text { 5. When you have } \\
\text { problem bus } \\
\text { companies show a } \\
\text { sincere interest to } \\
\text { solving }\end{array}$} & Frequency & 114 & 230 & 19 & 22 & 15 & \multirow[b]{2}{*}{1.99} & \multirow[b]{2}{*}{0.944} \\
\hline & Percentage & 28.5 & 57.5 & 4.8 & 5.5 & 3.8 & & \\
\hline
\end{tabular}

According to Table 3, the results show as following: 1) Accuracy of ticketing and billing services (Poor 43.5\%; Average 26.3\%; Strongly Poor 19.3\%; Good 7.3\%; and Excellence $3.8 \%$ ); 2) Buses departure and arrives at the punctual time (Poor 55.3\%; Strongly Poor 26.5\%; Average 9.0\%; Good 5.5\%; and Excellence 3.8\%); 3) Safe and security service (Poor 44.0\%; Strongly Poor 27.0\%; Average 20.3\%; Good 5.3\%; and Excellence 3.5\%); 4) Buses are never break down on the road (Poor 42.5\%; Strongly Poor 26.5\%; Average 21.5\%; Good 5.8\%; and Excellence 3.8\%); and 5) When you have problem bus companies show a sincere interest to solving (Poor 57.5\%; Strongly Poor 28.5\%; Average 4.8\%; Good 5.5\%; and Excellence $3.8 \%$ ). As results, the highest rating of reliability dimension was at "Poor" that had been rated 
by almost customers.

\subsubsection{Assurance}

Table 4. Customer's distribution of Assurance dimension based on expectation

\begin{tabular}{|c|c|c|c|c|c|c|c|c|}
\hline & & 1 & 2 & 3 & 4 & 5 & Mean & S.D \\
\hline \multirow{2}{*}{$\begin{array}{l}\text { 1. You feel safe in } \\
\text { your journey }\end{array}$} & Frequency & 76 & 198 & 91 & 20 & 15 & \multirow{2}{*}{2.22} & \multirow{2}{*}{0.946} \\
\hline & Percentage & 19.0 & 49.5 & 22.8 & 5.0 & 3.8 & & \\
\hline \multirow{2}{*}{$\begin{array}{l}2 . \quad \text { Staffs are } \\
\text { consistently } \\
\text { courteous with the } \\
\text { passenger }\end{array}$} & Frequency & 83 & 221 & 63 & 20 & 13 & \multirow[b]{2}{*}{2.15} & \multirow[b]{2}{*}{0.915} \\
\hline & Percentage & 20.8 & 55.3 & 15.8 & 5.8 & 3.3 & & \\
\hline \multirow{2}{*}{$\begin{array}{l}\text { 3. Driver and } \\
\text { conductor are } \\
\text { consistently polite }\end{array}$} & Frequency & 112 & 230 & 24 & 22 & 12 & \multirow{2}{*}{1.98} & \multirow{2}{*}{0.912} \\
\hline & Percentage & 28.0 & 57.5 & 6.0 & 5.5 & 3.0 & & \\
\hline \multirow{2}{*}{$\begin{array}{l}\text { 4. Driver } \\
\text { sufficient } \\
\text { driving skill }\end{array}$} & Frequency & 107 & 210 & 48 & 21 & 14 & \multirow{2}{*}{2.06} & \multirow{2}{*}{0.954} \\
\hline & Percentage & 26.8 & 52.5 & 12.0 & 5.3 & 3.5 & & \\
\hline \multirow{2}{*}{$\begin{array}{l}\text { 5. Staffs are friendly } \\
\text { and polite }\end{array}$} & Frequency & 110 & 222 & 33 & 22 & 13 & \multirow{2}{*}{2.02} & \multirow{2}{*}{0.934} \\
\hline & Percentage & 27.5 & 55.5 & 8.3 & 5.5 & 3.3 & & \\
\hline
\end{tabular}

In Table 4 presents to the satisfaction rating on assurance dimension which shows as follows: 1) You feel safe in your journey (Poor 49.5\%; Average 22.8\%; Strongly Poor 19.0\%; Good 5.0\%; and Excellence 3.8\%);2) Staffs are consistently courteous with the passenger (Poor 55.3\%; Strongly Poor 20.8\%; Average 15.8\%; Good 5.8\%; and Excellence 3.3\%); 3) Driver and conductor are consistently polite (Poor 57.5\%; Strongly Poor 28.0\%; Average 6.0\%; Good 5.5\%; and Excellence 3.0\%); 4) Driver have sufficient and driving skill (Poor 52.5\%; Strongly Poor 26.8\%; Average 12.0\%; Good 5.3\%; and Excellence 3.5\%); and 5) Staffs are friendly and polite (Poor 55.5\%; Strongly Poor 27.5\%; Average 8.3\%; Good 5.5\%; and Excellence 3.3\%). Therefore, with the results in table 5 indicates that almost customers rated on the satisfaction and expectoration of assurance dimension at "Poor". 
4.2.4 Empathy

Table 5. Customer's distribution of Empathy dimension based on expectation

\begin{tabular}{lllllllll}
\hline & 1 & 2 & 3 & 4 & 5 & Mean & S.D \\
\hline $\begin{array}{l}\text { 1. Bus companies } \\
\text { give a convenient }\end{array}$ & Frequency & 77 & 248 & 33 & 28 & 14 & & \\
$\begin{array}{l}\text { operating hours } \\
\text { Percentage }\end{array}$ & 19.3 & 62.0 & 8.3 & 7.0 & 3.5 & & 0.924 \\
$\begin{array}{l}\text { 2. Staffs understand } \\
\text { your specific needs }\end{array}$ & Frequency & 109 & 226 & 30 & 22 & 13 & & \\
$\begin{array}{l}\text { 3. Bus companies } \\
\text { have passenger inters }\end{array}$ & Frequency & 108 & 185 & 62 & 31 & 14 & & \\
at heart & Percentage & 27.0 & 46.3 & 15.5 & 7.8 & 3.5 & & \\
$\begin{array}{l}\text { 4. Customer loyalty } \\
\text { program Frequency }\end{array}$ & 110 & 185 & 73 & 19 & 13 & & \\
promotion and & Percentage & 27.5 & 46.3 & 18.3 & 4.8 & 3.3 & & \\
$\begin{array}{l}\text { 5. Bus companies } \\
\text { give special care for }\end{array}$ & Frequency & 115 & 207 & 45 & 19 & 14 & & \\
$\begin{array}{l}\text { women, children, } \\
\text { handicap and } \\
\text { vulnerable peoples. }\end{array}$ & Percentage & 28.8 & 51.8 & 11.3 & 4.8 & 3.5 & & \\
\hline
\end{tabular}

According to Table 5, the results show as following: 1) Bus companies give a convenient operating hour (Poor 62.0\%; Strongly Poor 19.3\%; Average 8.3\%; Good 7.0\%; and Excellence 3.5\%); 2) Staffs understand your specific needs (Poor 56.5\%; Strongly Poor 27.3\%; Average 7.5\%; Good 5.5\%; and Excellence 3.3\%); 3) Bus companies have passenger inters at heart (Poor 46.3\%; Strongly Poor 27.0\%; Average 15.5\%; Good 7.8\%; and Excellence $3.5 \%$ ); 4) Customer loyalty program and promotion (Poor 46.3\%; Strongly Poor 27.5\%; Average 18.3\%; Good 4.8\%; and Excellence 3.3\%); and 5) Bus companies give special care for women, children, handicap and vulnerable peoples (Poor 51.8\%; Strongly Poor 28.8\%; Average 11.3\%; Good 4.8\%; and Excellence 3.5\%). As results, the highest rating of empathy dimension was at "Poor" that had been rated by almost customers. 
4.2.5 Responsiveness

Table 6. Customer's distribution of Responsiveness dimension based on expectation

\begin{tabular}{|c|c|c|c|c|c|c|c|c|}
\hline & & 1 & 2 & 3 & 4 & 5 & Mean & S.D \\
\hline \multirow{2}{*}{$\begin{array}{l}\text { 1. Bus companies } \\
\text { provide specific time } \\
\text { and efficient service }\end{array}$} & Frequency & 111 & 203 & 46 & 23 & 14 & \multirow[b]{2}{*}{2.05} & \multirow[b]{2}{*}{0.972} \\
\hline & Percentage & 28.5 & 50.8 & 11.5 & 5.8 & 3.5 & & \\
\hline \multirow{2}{*}{$\begin{array}{l}2 . \text { Bus companies } \\
\text { always inform what } \\
\text { is available or } \\
\text { prohibit services }\end{array}$} & Frequency & 105 & 218 & 38 & 22 & 17 & \multirow[b]{2}{*}{2.07} & \multirow[b]{2}{*}{0.979} \\
\hline & Percentage & 26.3 & 54.5 & 9.5 & 5.5 & 4.3 & & \\
\hline \multirow{2}{*}{$\begin{array}{l}\text { 3.Communication } \\
\text { with staffs is clear } \\
\text { and helpful }\end{array}$} & Frequency & 76 & 232 & 55 & 25 & 12 & \multirow{2}{*}{2.16} & \multirow{2}{*}{0.907} \\
\hline & Percentage & 19.0 & 58.6 & 13.8 & 6.3 & 3.0 & & \\
\hline \multirow{2}{*}{$\begin{array}{l}\text { 4. Staffs are always } \\
\text { willing to serve you }\end{array}$} & Frequency & 76 & 247 & 39 & 25 & 13 & \multirow{2}{*}{2.13} & \multirow{2}{*}{0.903} \\
\hline & Percentage & 19.0 & 61.9 & 9.8 & 6.3 & 3.3 & & \\
\hline \multirow{2}{*}{$\begin{array}{l}\text { 5. Staffs are never } \\
\text { too busy to respond } \\
\text { to your request }\end{array}$} & Frequency & 75 & 233 & 52 & 27 & 13 & \multirow{2}{*}{2.18} & \multirow{2}{*}{0.923} \\
\hline & Percentage & 18.8 & 58.3 & 13.0 & 6.8 & 3.3 & & \\
\hline
\end{tabular}

In Table 6 presents to the satisfaction rating on assurance dimension which shows as follows: 1) Bus companies provide specific time and efficient service (Poor 50.8\%; Strongly Poor 28.5\%; Average 11.5\%; Good 5.8\%; and Excellence 3.5\%); 2) Bus companies always inform what is available or prohibit services (Poor 54.5\%; Strongly Poor 26.3\%; Average 9.5\%; Good 5.5\%; and Excellence 4.3\%); 3) Communication with staffs is clear and helpful (Poor 58.6\%; Strongly Poor 19.0\%; Average 13.8\%; Good 6.3\%; and Excellence 3.0\%); 4) Staffs are always willing to serve you (Poor 61.9\%; Strongly Poor 19.0\%; Average 9.8\%; Good $6.3 \%$; and Excellence 3.3\%); and 5) Staffs are never too busy to respond to your request (Poor 58.3\%; Strongly Poor 18.8\%; Average 13.0\%; Good 6.8\%; and Excellence 3.3\%). Therefore, with the results in table 7 indicates that almost customers rated on the satisfaction and expectoration of assurance dimension at "Poor".

\section{Discussion}

Firstly, the researcher would like to inform that the most important challenge in this research 
was the accuracy and biases of the result, and since it is quite difficult to find "clean" sample who has never used the service of bus transport before, and anyway if there were such sample, it is almost impossible for the researcher to release the questionnaire before the actually experience the service and collect it back when the sample has returned from their journey as every samples have different time schedule. The researcher have to admit that due to the above mentioned difficulties, the results in this research are considered to be used as a "guideline" of "which" and "what" are should the BTS of private companies of Cambodia improve its service quality rather than the question of "how" and "how much".

From the finding, on interesting finding was that in the question of customer's reason to use the BTS of private companies in Cambodia, in which "suitable traveling" ranked last among other factor (location convenience, appreciate prince, no choice, good service). Also, more than half of the respondents stated they maybe use the BTS again in the future, because there is no choice for them. Therefore, it can be clearly seen that this research was focusing at right point. Despite the fact that half of the respondents rated their satisfaction level of the "poor" level, and nearly half of the respondents rated their satisfaction level in "average" level. Nevertheless, not so many customers preferred to use the BTS because of its service convenience.

Clearly, there is still opportunity for the improvements to be done in order to increase the customer satisfaction on service quality. Therefore, it is considered very important that the BTS of private companies in Cambodia to improve its service quality in every dimension (tangible, reliability, assurance, empathy, and responsiveness), in order to maintain existing customer, regain the lost, as well as attracting new customer.

\section{Conclusion}

The research of “ Improving Service Quality and Customer's Satisfaction on Bus Transport Sector of Cambodia" was aimed to study and find out the results of customer's satisfaction with the BTS provided by private companies in Cambodia that serve the traveling from Phnom Penh to Poipot, that is the rush traffic in Cambodia. Service quality is an important consideration in a successful service business. Above all, a great service can only be delivered on the basis of meeting with the customer's requirement and satisfaction. By the time, this research was conducted, the highly competitive market conditions in Cambodia's bus transport service industry had forced service operators to deliver high-quality service to customers. In order to provide that, the service operators should first focus on understanding customers' needs and their expectations before implementing the suitable service strategy to meet the customers' needs.

\section{Acknowledgement}

The author would like to thank her advisor for help and advices. Also, the author prefers to thank the anonymous reviewers and the academic editor of this journal for the invaluable comments and suggestions which have substantially improved the manuscript. Moreover, the author would like to especially acknowledge to Dr. Suy Rathny for help and correct English grammar and vocabulary. 


\section{References}

Alan, W., Valarie A., Z., Mary Jo, B., \& Dwayne D., G. (2012). Services Marketing: Integrating Customer Focus Across the Firm (2 ed.). Europe: McGraw-Hill Education.

Brown, T. J., Churchill, G. A., \& Peter, J. P. (1993). Improving the measurement of service quality. Journal of Retailing, 69(1), 127-139. https://doi.org/10.1016/S0022-4359(05)80006-5 Candido, C. J. F., \& Morris, D. S. (2000). Charting service quality gaps. Total Quality Management, 11(4-6), 463-472. https://doi.org/10.1080/09544120050007779

Cronin Jr, J. J., Brady, M. K., \& Hult, G. T. M. (2000). Assessing the effects of quality, value, and customer satisfaction on consumer behavioral intentions in service environments. Journal of Retailing, 76(2), 193-218. https://doi.org/10.1016/S0022-4359(00)00028-2

Eden, S. (2005). Rethinking the role of transportation in tourism. Proceedings of the Eastern Asia Society for Transportation Studies, 5, 1767-1777.

Eugene, W. A., \& Vikas, M. (2000). Strengthening the Satisfaction-Profit Chain. Journal of Service Research, 3(2), 107-120. https://doi.org/10.1177/109467050032001

Hoffman, K., \& Bateson, J. (2006). Services marketing: Concepts, strategies and cases (3 ed.): Mason, $\mathrm{OH}$ : Thomson /South-Western.

Jain, S. K., \& Gupta, G. (2004). Measuring Service Quality: SERVQUAL vs. SERVPERF Scales. The Journal for Decision Makers, 29(4), 25-37. https://doi.org/10.1177/0256090920040203

Jenet Manyi, A. (2011). The Relationship between Customer Satisfaction and Service Quality: a study of three Service sectors in Umeå. (Master), Umeå

Kuo, Y.-F. (2003). A study on service quality of virtual community websites. Total Quality Management \& Business Excellence, 14(4), 461-473. https://doi.org/10.1080/1478336032000047237a

Manjunatha, K., \& Shivalingaiah, D. (2004). Customer's perception of service quality in libraries. Annals of library and information studies, 54(4), 145-151.

Nyer, P. U. (1996). The Determinants of Satisfaction: an Experimental Verification of the Moderating Role of Ambiguity. Advances in Consumer Research Journal, 23, 255-259.

Oliver, R. L., \& Swan, J. E. (1989). Equity and Disconfirmation Perceptions as Influences on Merchant and Product Satisfaction. Journal of Consumer Research, 16(3), 372-383. https://doi.org/10.1086/209223

Parasuraman, A., Valarie A., Z., \& Leonard L., B. (1985). A Conceptual Model of Service Quality and Its Implications for Future Research. Journal of Marketing, 49(4), 41-50. https://doi.org/10.2307/1251430

Parasuraman, A., Valarie A., Z., \& Leonard L., B. (1988). SERVQUAL: A Multiple-Item Scale for Measuring Consumer Perceptions of Service Quality. Journal of Retailing and Marketing Studies, 64(1), 12-40.

Rabiul, I., Mohammed S., C., Mohammad, S. S., \& Salauddin, A. (2014). MEASURING CUSTOMER'S SATISFACTION ON BUS TRANSPORTATION. American Journal of Economics and Business Administration, 6(1), 34-41. 
https://doi.org/10.3844/ajebasp.2014.34.41

Rida, K., Hummayoun, N., Sana, E., Faiza, M., \& Taha, B. (2012). SERVICE QUALITY AND CUSTOMER SATISFACTION IN PUBLIC TRANSPORT SECTOR OF PAKISTAN: An Empirical Study. International Journal of Economics and Management Sciences, 1(9), 24-30.

Tirimba O., M., Richard B., N., Robert M., B., Thomas O., O., \& Tom O., K. (2013). Service Quality and Customer Satisfaction at Kenya Airways Ltd. European Journal of Business and Management, 5(22), 170-179.

Valarie A., Z., Leonard L., B., \& Parasuraman, A. (1993). The nature and determinants of customer expectations of service. Journal of the Academy of Marketing Science, 21(1), 1. https://doi.org/10.1177/0092070393211001

Valarie A., Z., Mary Jo, B., \& Dwayne, G. (2006). Services marketing (4 ed.): McGraw-Hill; International Ed edition.

Valarie A., Z., Parasuraman, A., \& Leonard L., B. (1990). Delivering Quality Service: Balancing Customer Perceptions and Expectations (1 ed.). New York, USA: Free Press.

Veronica, K., Jacqueline, M., \& Melissa-Ray, S. (2015). Customer satisfaction in Public Transportation: A case study of SJ traveler's perception in Sweden. Mälardalen University.

\section{Copyright Disclaimer}

Copyright for this article is retained by the author(s), with first publication rights granted to the journal.

This is an open-access article distributed under the terms and conditions of the Creative Commons Attribution license (http://creativecommons.org/licenses/by/3.0/). 